\title{
Organ-Protective Effect of Red Ginger Extracts in Male Mice Induced by Paraquat
}

\author{
Kamiliah Tsany, *Sutyarso, M. Kanedi, Hendri Busman \\ Jurusan Biologi, FMIPA, Universitas Lampung \\ Jalan Prof. Dr. Soemantri Brojonegoro No. 1 Bandar Lampung, Lampung 35145 \\ *Email: sutyarso@yahoo.co.id
}

\begin{abstract}
Paraquat is a toxic compound that disrupts biochemical processes in the body, cell death, and multi-organ failure. The liver and lung are the target organ of paraquat toxicity. The body needs antioxidants to counteract free radicals. Red ginger (Zingiber officinale Roxb. Var rubrum) is a spice that contains antioxidants. This study was conducted to determine the effect of ethanol extract of red ginger (Zingiber officinale Roxb. Var rubrum) on liver and lung histology male mice induced by paraquat. The research used completely randomized design and use of 6 treatment groups, i.e. control group (given distilled water and standard feed), PQ group (induced by paraquat $20 \mathrm{mg} / \mathrm{kg}$ per BW), group P1 (given paraquat and ethanol extracts of red ginger $200 \mathrm{mg} / \mathrm{kg}$ per BW), group P2 (given paraquat and ethanol extract of red ginger $400 \mathrm{mg} / \mathrm{kg}$ per BW), group P3 (given paraquat and ethanol extract of red ginger $600 \mathrm{mg} / \mathrm{kg}$ per BW), group P4 (given ethanol extract of red ginger extract $600 \mathrm{mg} / \mathrm{kg}$ per BW). The data obtained will be tested using One Way ANOVA and continued by Least Significant Difference (LSD) with a 95\% confidence level. The results showed ethanol extract of red ginger effective against liver and lung histology male mice induced by paraquat. The results also showed ethanol extract of red ginger with a dose of $400 \mathrm{mg} / \mathrm{kg}$ per BW is effective in protecting the liver and lung from damage caused induced by paraquat.
\end{abstract}

Keywords: Red ginger (Zingiber officinale Roxb. Var rubrum), paraquat, antioxidant, liver, lung.

\section{PENDAHULUAN}

Paraquat merupakan senyawa yang sangat toksik yang terkandung dalam herbisida dan dapat memasuki tubuh dengan cara tertelan, terhirup, dan melalui kontak dengan kulit atau mata. Apabila terpapar senyawa ini, dapat berpengaruh pada organ-organ penting, terutama hati dan paru yang merupakan organ target dari efek toksisitas paraquat yang paling parah.

Paraquat menyebabkan kerusakan yang luas terhadap mitokondria sel melalui produksi radikal bebas dan stress oksidatif, yang mengakibatkan gangguan proses penting biokimia dalam tubuh, kematian sel, dan kegagalan multi-organ (Suntres, 2002; Mohammadi dan Ghazi,
2008; Cocheme dan Murphy, 2009). Selain itu, paraquat juga menyebabkan peningkatan reaksi oksidasi di dalam tubuh dengan cara dimetabolisme oleh berbagai enzim seperti NADPH sehingga meningkatkan Reactive Oxygen Species (Haliwell dan Whiteman, 2004).

Tubuh membutuhkan antioksidan untuk menangkal radikal bebas yang masuk ke dalam tubuh. Senyawa antioksidan ini dapat menghalangi kerusakan oksidatif melalui reaksi reduksi dengan radikal bebas. Salah satu tanaman herbal yang mengandung antioksidan adalah jahe merah (Zingiber officinale Roxb. var rubrum). Jahe merah merupakan jenis rempah-rempah yang mengandung antioksidan yang cukup tinggi (Shobana dan Naidu, 2000). Dalam ekstrak jahe 
merah terkandung senyawa bioaktif seperti gingerol, shagaol, zingerone, diarelhiptanoid, curcumin, saponin, dan flavonoid yang berperan sebagai antioksidan (Zakaria 2000; Veena, 2009).

Oleh karena itu, penelitian ini bertujuan untuk mengetahui pengaruh ekstrak etanol jahe merah sebagai suplemen antioksidan terhadap histologi hati dan paru mencit jantan ysng diinduksi paraquat.

\section{METODE PENELITIAN}

Rancangan percobaan dalam penelitian ini menggunakan Rancangan Acak Lengkap (RAL) dengan menggunakan 24 ekor mencit jantan sebagai hewan uji yang kemudian dibagi mengjadi 6 kelompok perlakuan, yaitu kelompok kontrol (K), kelompok paraquat (PQ), kelompok paraquat + ekstrak etanol jahe merah 200 mg/kgBB (P1), kelompok paraquat + ekstrak etanol jahe merah 400 $\mathrm{mg} / \mathrm{kgBB}$ (P2), kelompok paraquat + ekstrak etanol jahe merah $600 \mathrm{mg} / \mathrm{kgBB}$ (P3), dan kelompok ekstrak etanol jahe merah $600 \mathrm{mg} / \mathrm{kgBB}$ (P4).

Pemberian perlakuan dilakukan secara oral menggunakan sonde lambung dan diberikan setiap hari selama 35 hari. Sedangkan induksi herbisida paraquat diberikan pada hewan uji sebanyak 6 kali selama 3 minggu. Setelah 35 hari perlakuan, dilakukan nekropsi. Mencit dikorbankan dengan cara inhalasi menggunakan kloroform kemudian dilakukan pembedahan untuk diambil organ hati dan paru. Lalu organ ditimbang dengan mengunakan timbangan analitik. Setelah itu, organ dimasukkan dalam wadah yang berisi larutan buffer formalin $10 \%$. Pembuatan preparat histologi hati dan paru menggunakan metode paraffin dengan pewarnaan Hematoxylin Eosin.

Preparat histologi hati dan paru diamati di bawah mikroskop cahaya pada 5 lapang pandang yang berbeda dengan perbesaran 100x dan 400x. Setiap 5 lapang pandang diamati 20 sel secara acak, sehingga dalam satu preparat teramati 100 sel. Penilaian kerusakan jaringan hati dinilai menggunakan skoring Histopathology Manja Roenigk (Maulida dkk., 2013) dengan kerusakan yang diamati meliputi degenerasi parenkimatosa, degenerasi hidropik, dan nekrosis. Sedangkan kerusakan jaringan paru-paru, jenis kerusakan yang diamati meliputi penebalan dinding alveolus, infiltrasi sel radang, dan pendarahan. Setelah itu, sel yang teramati dicatat dan dihitung jumlah persentase kerusakan yang terjadi.

Data penelitian akan dianalisis menggunakan One Way ANOVA dan uji Beda Nyata Terkecil (BNT) dengan tingkat kepercayaan 95\% untuk menguji perbedaan rerata antar kelompok perlakuan.

\section{HASIL DAN PEMBAHASAN}

\section{Perubahan berat badan mencit}

Pengaruh pemberian ekstrak jahe merah terhadap berat badan mencit tidak menunjukkan adanya pengaruh signifikan $(P>0,05)$. Tetapi pada (Tabel 1) terlihat bahwa pemberian ekstrak etanol jahe merah berpengaruh terhadap perubahan berat badan mencit yang diinduksi paraquat. Hal ini diduga karena jahe merah dapat meningkatkan nafsu makan mencit selama percobaan. Selain itu, kemampuan jahe merah sebagai antioksidan alami yang tidak terlepas dari kadar komponen fenolik total yang terkandung di dalamnya. Gingerol dan shogaol merupakan senyawa yang diidentifikasi sebagai komponen antioksidan fenolik dalam jahe (Kusumaningati, 2009).

\section{Berat organ hati dan paru mencit}

Pemberian ekstrak etanol jahe merah tidak berpengaruh signifikan $(P>0,05)$ terhadap berat organ hati dan paru mencit 
yang diinduksi paraquat. Kelompok PQ yang diinduksi paraquat menunjukkan peningkatan berat organ hati dan paru.
Berat organ hati mencit kelompok P1 dan kelompok P2 memiliki nilai rata-rata berat organ yang mendekati kelompok kontrol.

Tabel 1. Perubahan berat badan mencit (g) pada setiap kelompok perlakuan.

\begin{tabular}{|c|c|c|c|c|}
\hline \multirow{2}{*}{ Kelompok Perlakuan } & \multicolumn{4}{|c|}{  } \\
\hline & Hari ke-0 & Hari ke-21 & Hari ke-35 & \\
\hline Kontrol (K) & & $34.65 \pm 1.56$ & $34.25 \pm 1.15$ & $34.32 \pm 1.40$ \\
\hline Paraquat (PQ) & $33.65 \pm 1.48$ & $31.55 \pm 1.32$ & $32.35 \pm 1.14$ & $33.93 \pm 1.49$ \\
\hline $\begin{array}{l}\text { Paraquat+Jahe } \\
200 \mathrm{mg} / \mathrm{kgBB}(\mathrm{P} 1)\end{array}$ & $34.57 \pm 0.84$ & $31.77 \pm 1.92$ & $33.40 \pm 1.82$ & $30.45 \pm 2.84$ \\
\hline $\begin{array}{l}\text { Paraquat+Jahe } \\
400 \mathrm{mg} / \mathrm{kgBB}(\mathrm{P} 2)\end{array}$ & $33.35 \pm 1.09$ & $28.37 \pm 0.92$ & $30.95 \pm 0.59$ & $31.47 \pm 0.98$ \\
\hline $\begin{array}{l}\text { Paraquat+Jahe } \\
600 \mathrm{mg} / \mathrm{kgBB}(\mathrm{P} 3)\end{array}$ & $34.55 \pm 1.67$ & $31.30 \pm 1.63$ & $31.40 \pm 1.13$ & $33.75 \pm 1.38$ \\
\hline Jahe $600 \mathrm{mg} / \mathrm{kgBB}(\mathrm{P} 4)$ & $33.87 \pm 1.36$ & $30.92 \pm 1.92$ & $33.47 \pm 1.46$ & $34.30 \pm 1.78$ \\
\hline
\end{tabular}

Sedangkan berat organ paru mencit kelompok P2 yang diberi ekstrak etanol jahe merah dosis $400 \mathrm{mg} / \mathrm{kgBB}$ memiliki nilai berat rata-rata yang mendekati kelompok K (Gambar 2).

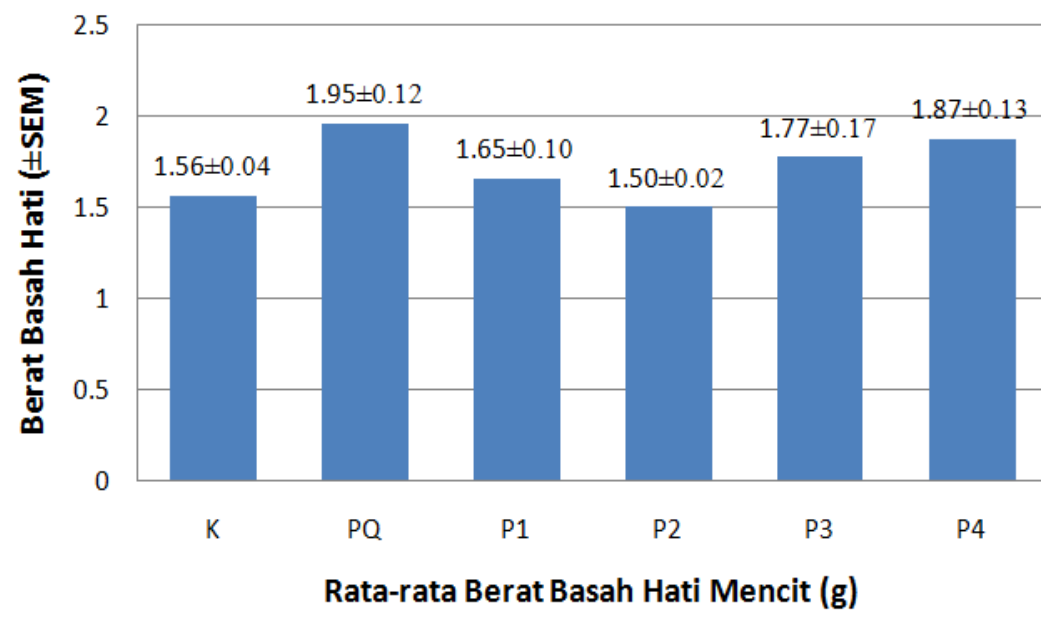

Gambar 1. Rata-rata $( \pm S E M)$ berat organ hati mencit kelompok kontrol $(K)$, paraquat $(P Q)$, paraquat + ekstrak etanol jahe merah $200 \mathrm{mg} / \mathrm{kgBB}$ (P1), paraquat + ekstrak etanol jahe merah $400 \mathrm{mg} / \mathrm{kgBB}$ (P2), paraquat + ekstrak etanol jahe merah $600 \mathrm{mg} / \mathrm{kgBB}$ (P3), dan ekstrak etanol jahe merah $600 \mathrm{mg} / \mathrm{kgBB}$ (P4).

Perubahan berat organ pada hewan percobaan merupakan tanda adanya perubahan sel pada organ yang diakibatkan oleh terpapar senyawa kimia (Robbins dkk., 2007). Peningkatan berat organ hati yang dapat disebabkan oleh pembendungan pembuluh vena dan peningkatan tekanan hidrostatik. Peningkatan tekanan hidrostatik dapat menimbulkan perembesan cairan plasma ke dalam ruang interstitium yang kemudian akan mengisi sela-sela jaringan ikat longgar dan rongga badan sehingga dapat menimbulkan pembengkakan pada sel hepatosit (Wulandari, 2006).

Pemberian ekstrak etanol jahe merah terhadap mencit yang diinduksi paraquat terjadi penurunan berat organ hati dan paru. Hal ini membuktikan bahwa ekstrak etanol jahe merah memiliki kemampuan dalam melindungi organ hati dan paru dari 
kerusakan yang disebabkan oleh radikal bebas yang berasal dari induksi paraquat.

Selain itu, aktifitas antioksidan tertinggi dalam jahe merah ditunjukkan oleh gingerol yang berperan sebagai peredam radikal bebas endogen atau metabolit lainnya (Tejasari dan Zakaria, 2000).



Gambar 2. Rata-rata $( \pm S E M)$ berat organ paru mencit kelompok kontrol $(K)$, paraquat $(P Q)$, paraquat + ekstrak jahe $200 \mathrm{mg} / \mathrm{kgBB}(\mathrm{P} 1)$, paraquat + ekstrak jahe $400 \mathrm{mg} / \mathrm{kgBB}$ (P2), paraquat + ekstrak jahe $600 \mathrm{mg} / \mathrm{kgBB}$ (P3), dan ekstrak jahe $600 \mathrm{mg} / \mathrm{kgBB}$ (P4).

\section{Derajat kerusakan jaringan dan gambaran histologi hati}

Pemberian ekstrak etanol jahe merah berpengaruh signifikan $(P<0,05)$ terhadap histologi hati mencit jantan yang diinduksi paraquat. Pada grafik (Gambar 3), kelompok $\mathrm{PQ}$ memiliki skor rata-rata paling tinggi di antara kelompok perlakuan. Berdasarkan hasil pengamatan histologi, kelompok $\mathrm{PQ}$ menunjukkan kerusakan yang paling parah dengan persentase kerusakan $>50 \%$. Induksi paraquat akan menimbulkan stress oksidatif yang menghasilkan hidrogen peroksida sehingga mengakibatkan kerusakan sel hepatosit. Menurut Trisnowati (2009), hidrogen peroksida dapat beraksi dengan senyawa dalam tubuh dan membentuk radikal hidroksil yang sangat reaktif. Radikal hidroksil tersebut menyebabkan peroksidasi lipid. Peroksidasi lipid menyebabkan kerusakan membran sel dan kemudian mengakibatkan struktur sel menjadi tidak normal dan merusak fungsi sel.

Meningkatnya radikal bebas di dalam sel hepatosit menyebabkan hilangnya regulasi intraseluler. Hilangnya regulasi tersebut menyebabkan berkurangnya kemampuan sel hepatosit dalam melakukan transport aktif ion natrium yang berakibat masuknya air dalam jumlah berlebihan ke dalam sel sehingga terjadi kerusakan pada membran sel hepatosit (Indika dan Buckley, 2011). Paraquat menyebabkan kerusakan jaringan hati dengan adanya degenerasi vakuola pada hepatosit dan pelebaran pada pembuluh darah vena (Awadalla, 2012).

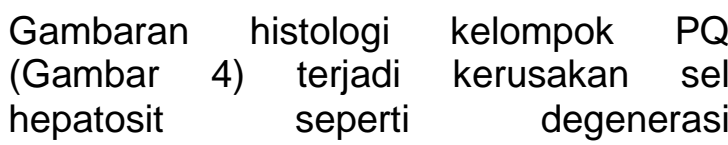
parenkimatosa, degenerasi hidropik, degenerasi lemak, dan nekrosis. Selain itu, terjadi kongesti pada sinusoid dan vena sentralis serta ditemukan sel radang. Sel hepatosit yang mengalami degenerasi parenkimatosa terlihat adanya granulagranula dalam sitoplasma yang merupakan endapan protein, sehingga sitoplasma sel menjadi keruh dan terjadi pembengkakan. Sedangkan degenerasi hidropik ditandai dengan adanya vakuola yang berisi air dalam sitoplasma yang mengakibatkan sitoplasma menjadi pucat dan membengkak (Bhara, 2009). Degenerasi lemak terjadi akibat perubahan metabolisme lemak (trigliserida) sehingga terjadi peningkatan 
sintesis atau menurunnya sekresi lemak dalam sel (Swarayama dkk., 2012).

Radang merupakan salah satu respon fisiologi terhadap cedera jaringan. Infiltrasi sel radang limfosit pada vena sentralis disebabkan karena rusaknya sel endotel yang sangat peka terhadap zat racun. Peradangan pada hepar dimulai pada vena sentralis sebagai tempat penampungan darah yang berasal dari arteri hepatika dan vena porta. Akibat pembendungan ini sirkulasi darah terganggu dan dapat mengakibatkan sel hepar mengalami degenerasi hingga nekrosis karena kekurangan natrium dan oksigen (Greaves dkk., 2000).

e

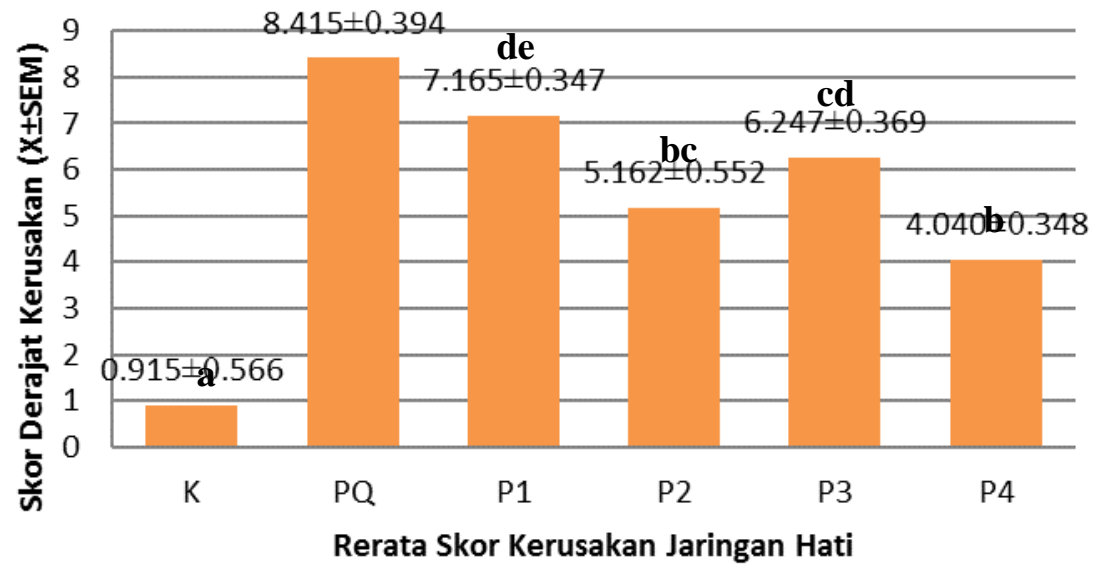

Gambar 3. Grafik rata-rata skor derajat kerusakan jaringan hati mencit kelompok kontrol (K), paraquat (PQ), paraquat + ekstrak jahe $200 \mathrm{mg} / \mathrm{kgBB}(\mathrm{P1})$, paraquat + ekstrak jahe $400 \mathrm{mg} / \mathrm{kgBB}$ (P2), paraquat + ekstrak jahe $600 \mathrm{mg} / \mathrm{kgBB}$ (P3), dan ekstrak jahe 600 $\mathrm{mg} / \mathrm{kgBB}$ (P4). Skor rerata yang diikuti huruf yang berbeda menunjukkan adanya perbedaan yang signifikan berdasarkan uji BNT pada taraf nyata 95\%.

Hasil uji lanjut BNT menunjukkan kelompok $\mathrm{PQ}$ dan $\mathrm{P} 1$ tidak berbeda signifikan $(P>0,05)$, sehingga pemberian ekstrak etanol jahe merah dosis 200 $\mathrm{mg} / \mathrm{kgBB}$ belum efektif dalam melindungi dan memperbaiki jaringan hati mencit. Sedangkan kelompok $P Q$ berbeda signifikan dengan kelompok P2 dan kelompok P3. Pada (Gambar 3), kelompok P2 memiliki nilai rata-rata derajat kerusakan jaringan hati yang paling kecil diantara kelompok $P Q$, kelompok P1, dan kelompok P3. Hasil ini membuktikan bahwa kelompok P2 yang diberi ekstrak etanol jahe merah dosis 400 $\mathrm{mg} / \mathrm{kgBB}$ efektif dalam melindungi dan memperbaiki jaringan hati mencit yang diinduksi paraquat.

Berdasarkan hasil penelitian, ekstrak etanol jahe merah mengandung senyawa antioksidan yang mampu meredam efek radikal bebas dalam tubuh. Ekstrak jahe merah dapat mengurangi perubahan histopatologi pada organ hati, sehingga ekstrak jahe merah memiliki sifat hepatoprotektif terhadap kerusakan yang disebabkan oleh radikal bebas (Ahmed, 2015). Senyawa fenol yang terdapat pada ekstrak jahe merah telah dibuktikan berperan sebagai senyawa antioksidan yang bersifat hepatoproktektor terhadap jaringan hati yang terpapar senyawa toksik (Fathir, 2010). Berdasarkan penelitian Anshari dkk. (2006), ekstrak jahe merah yang diberikan pada tikus selama 20 hari dapat meredakan nekrosis miokard oksidatif akibat kelebihan radikal bebas dengan cara meningkatkan kadar antioksidan dalam tubuh.

Sedangkan kelompok $\mathrm{P} 4$ yang hanya diberi ekstrak jahe dosis $600 \mathrm{mg} / \mathrm{kgBB}$ tampak terjadi kerusakan pada sel hepatosit seperti degenerasi hidropik, degenerasi lemak, dan sel radang. Selain 



Keterangan :

VS : Vena sentral

DP : degenerasi parenkimatosa

$S$ : sinusoid

$\mathrm{SH}:$ sel hepatosit normal

SK : sel Kupffer

$\mathrm{K}$ : kongesti

$\mathrm{DH}$ : degenerasi hidropik

$\mathrm{N}$ : nekrosis

$\mathrm{SR}:$ sel radang

$\mathrm{Ka}$ : karioreksis

Gambar 4. Struktur histologi hati mencit dengan perbesaran 400x. (A) kelompok kontrol (K), (B) kelompok paraquat $(P Q),(C)$ kelompok paraquat + jahe 200 mg/kgBB (P1), (D) kelompok paraquat + jahe $400 \mathrm{mg} / \mathrm{kgBB}(\mathrm{P} 2)$, (E) kelompok paraquat + jahe $600 \mathrm{mg} / \mathrm{kgBB}(\mathrm{P} 3)$, dan (F) kelompok jahe $600 \mathrm{mg} / \mathrm{kgBB}(\mathrm{P} 4)$.

Bagian sinusoid tampak normal dan tidak menunjukkan adanya pelebaran. Sebuah penelitian menunjukkan bahwa ekstrak jahe dengan dosis $500 \mathrm{mg} / \mathrm{kgBB}$ yang diberikan secara intraperitoneal pada tikus betina bersifat sedikit toksik. Pengujian histopatologi pada paru-paru dan hati juga membuktikan bahwa pemberian ekstrak jahe $500 \mathrm{mg} / \mathrm{kgBB}$ menunjukkan adanya abnormalitas pada jaringan seperti 
penebalan dinding alveolus pada paru, pembengkakan hepatosit, dan pelebaran sinusoid (Alnaqeeb dkk., 2003).

\section{Derajat kerusakan jaringan dan gambaran histologi paru}

Berdasarkan hasil penelitian, pemberian ekstrak jahe merah terhadap histologi paru mencit yang diinduksi paraquat menunjukkan adanya pengaruh yang signifikan $(\mathrm{P}<0,05)$ antar kelompok perlakuan. Hasil yang diperoleh dapat dilihat pada (Gambar 5). Kelompok $P Q$ yang hanya diinduksi paraquat mengalami kerusakan jaringan paru yang paling tinggi dibandingkan kelompok lainnya.



Gambar 5. Rata-rata skor kerusakan jaringan paru kelompok kontrol $(K)$, paraquat $(P Q)$, paraquat + jahe $200 \mathrm{mg} / \mathrm{kgBB}$ (P1), paraquat + jahe $400 \mathrm{mg} / \mathrm{kgBB}$ (P2), paraquat + jahe 600 $\mathrm{mg} / \mathrm{kgBB}$ (P3), dan ekstrak jahe $600 \mathrm{mg} / \mathrm{kgBB}$ (P4). Skor rata-rata yang diikuti huruf yang berbeda menunjukkan adanya perbedaan yang signifikan berdasarkan uji BNT pada taraf nyata $95 \%$.

Gambaran histologi paru menunjukkan adanya penebalan dinding alveolar, infiltrasi sel radang disekitar bronkiolus dan dinding alveolar, serta terjadi pendarahan. Akumulasi paraquat di dalam sel alveolar, akan memproduksi Reactive Oxygen Species (ROS) intraseluler sehingga terjadi inflamasi (peradangan) dan fibrosis. Radang merupakan salah satu respon fisiologi lokal terhadap cedera jaringan. Infiltrasi sel radang limfosit di sekitar bronkiolus disebabkan karena rusaknya sel endotel yang sangat peka terhadap senyawa toksik (Greaves et al., 2000). ROS dapat mendorong terjadinya peroksidasi lipid, gangguan membrane permeabilitas mitokondria, dan kerusakan sitoskeletal yang memicu kerusakan sel (Fukushima dkk., 2002). Sel yang berisi DNA yang telah rusak menyebabkan sel menjadi abnormal dalam pembelahannya (Tuminah, 1999). Proliferasi terjadi karena proses pembelahan sel yang terus menerus tanpa terkendali, sehingga mengakibatkan penebalan dinding alveolus.

Berdasarkan data penelitian (Gambar 5), kelompok P1 dan kelompok $\mathrm{PQ}$ tidak berbeda signifikan, tetapi kelompok P1 memiliki skor rata-rata kerusakan jaringan yang lebih rendah dari pada kelompok $P Q$. Hasil pengamatan kelompok P1 terjadi kerusakan jaringan $>50 \%$ serta terlihat penebalan dinding alveolar, infiltrasi sel radang, dan pendarahan. Sedangkan kelompok P2 dan kelompok P3 terdapat perbedaan signifikan dengan kelompok PQ. Berdasarkan hasil pengamatan kelompok P2 dan kelompok P3 memperlihatkan kondisi jaringan yang lebih baik dibandingkan kelompok $\mathrm{P} 1$ dan kelompok PQ. Namun, masih terlihat adanya penebalan dinding alveolar, infiltrasi sel radang, dan pendarahan 




Gambar 6. Struktur histologi paru mencit dengan perbesaran 400x. (A) kelompok kontrol (K),

(B) kelompok paraquat (PQ), (C) kelompok paraquat + jahe $200 \mathrm{mg} / \mathrm{kgBB}(\mathrm{P1})$,

(D) kelompok paraquat + jahe $400 \mathrm{mg} / \mathrm{kgBB}$ (P2), (E) kelompok paraquat + jahe $600 \mathrm{mg} / \mathrm{kgBB}(\mathrm{P} 3)$, dan (F) kelompok jahe $600 \mathrm{mg} / \mathrm{kgBB}(\mathrm{P} 4)$.

ringan. Hal ini membuktikan bahwa pemberian ekstrak etanol jahe merah yang diberikan secara oral mampu melindungi dan mencegah kerusakan jaringan paru mencit yang diinduksi paraquat selama percobaan.
Jahe merah dapat bersifat sebagai penghambat proliferasi sel, antioksidan, dan antikanker. Beberapa komponen utama dalam jahe seperti gingerol, shogaol, dan gingeron memiliki kandungan antioksidan yang lebih tinggi 
dibandingkan vitamin E (Kikuzaki dan Nakatani, 1993). Gingerol merupakan senyawa aktif yang terkandung dalam jahe merah yang berfungsi sebagai antioksidan dan inhibitor suatu enzim yang menghasilkan anion superoksida dan menghambat terjadinya proliferasi sel oleh radikal bebas (Arobi, 2010).

\section{KESIMPULAN}

Pemberian ekstrak etanol jahe merah (Zingiber officinale Roxb. var rubrum) efektif melindungi jaringan hati dan paru mencit jantan yang diinduksi paraquat. Pada penelitian ini, Ekstrak etanol jahe merah dengan dosis $400 \mathrm{mg} / \mathrm{kgBB}$ paling efektif dalam melindungi hati dan paru dari kerusakan akibat induksi paraquat.

\section{DAFTAR PUSTAKA}

Ahmed, G. M. J., Soeharto, S., Sujuti, H. (2015). The effect of ginger (Zingiber officinale Roscoe) extract on liver histopathology and alanine aminotransferase serum level in carbofuran-induced rats. International Journal of PharmTech Research, 8(5), 889-897.

Anshari, M. N., Bhandari, U., Pillai, K. K. (2006). Ethanolic Zingiber officinale $r$. extract pretreatment alleviates isoproterenolinduced oxidative neocardial necrosis in rats. Indian Journal of Experimental Biology, 44, 892-897.

Arobi, I. (2010). Pengaruh ekstrak jahe merah (Zingiber officinale Rosc.) terhadap perubahan pelebaran alveolus paru-paru tikus (Rattus norvegicus) yang terpapar allethrin (Skripsi). Malang: Universitas Islam Negeri Maulana Malik Ibrahim Malang.

Awadalla, A.E. (2012). Efficacy of vitamin $C$ against liver and kidney damage induced byparaquat toxicity. Exp Toxicol Pathol, 64(5), 431.

(Angelica keiskel). Buletin Veteriner Udayana, 4(2), 119-125.
Cocheme, H. M. dan Murphy, M. P. (2009). The uptake and interactions of the redox cycler paraquat with mitochondria. Method Enzymol, 456, 395-417.

Fukushima, T., Tawara, K., Lim, H., Moriyama, M. (2002). Mechanism of cytotoxicity of $P Q$. Environ. Health Perspect Med, 7, 89-94.

Greaves, M.B.P., Ch, B., Path, F.R.C. (2000). Histopathology of Preclinical Toxicity Studies. Amsterdam: Elsevier.

Indika, G. and Buckley, N. (2011). Medical management of paraquat ingestion. British Journal of Clinical Pharmacology.

Kikuzaki, H., Nakatani, N. (1993). Antioksidant effects of some ginger constituens. J. Food Science, $58,1.407-1.410$.

Mohammadi, B. A. dan Ghazi, K. M. (2008). Alter-native electron acceptors: Proposed mechanism of paraquat mitochondrial toxicity. Environ Toxicol Pharmacol, 26(1), 15.

Robbins S.L., R. S. Cotran, and V. Kumar .(2007). Buku Ajar Patologi (Edisi ke7). Jakarta: EGC.

Shobana, S. dan Naidu, K. A. (2000). Antioxidant Actifity, of Selected Indian Spices. Dalam Prostaglandins Leukotriene Essential Fatty Acid.

Suntres, Z.E. (2002). Role of antioxidants in paraquat toxicity. Toxicology, 180, 65-77.

Swarayama, I. M. I., Sudira, I. W., Berata, I. K. (2012). Perubahan Histopatologi Hati Mencit (Mus musculus) yang diberikan Ekstrak Daun Ashitaba

Tejasari, dan Zakaria, F. R. (2000). Sifat Fungsional Jahe: Fraksi 1 dan 2 Senyawa Bioaktif Oleoresin Rimpang Jahe Menurunkan produk Peroksidasi 
Lipid Membran Sel Limfosit secara in Vitro. Prosiding Seminar Nasional Industri Pangan.

Veena, M. A. dan Verma, R. J. (2009). Ameliorative effects of ginger extract on paraben induced lipid oeroxidation in the liver of mice. Acta Polinae Pharmacoutica. 66, 225-228.
Zakaria, F. R., Santoso, H., dan Haryono, A. (2000). Pengaruh konsumsi jahe (Zingiber officinale Roscoe) terhadap kadar maloaldehida dan vitamin e plasma pada mahasiswa pesantren Ulil Albaab Kedung Badak Bogor. Teknologi dan Industri Pangan, 11, 36 